and cheese. And for this your construction of the law of partnership would have made me pay as much as for a handsome income; giving me the simple and not very pleasant alternative, either to live on the scanty bread and cheese, or try my luck elsewhere, minus my capital.

The senior partner, who sticks to the money, of course says, "Oh! you have a fine thing of it; you have been introduced. forsooth, to society, with which, in the natural course of things, you would never have mixed," (the bulk of the patients being perhans railway porters and second-rate shopkeepers). " Tou have the chance of walking off with the greater part of the practice," (with the "asicle," probably, to his dear friend the counsel. "Won't you wish you may get it !") "And, at the worst, you have a nice nucleus, in a first-rate neighbourhood, which is worth all the money."

A fine thing, certainly, to have spent all your capital, in order to be elevated so much above your natural level; and to have a "nice nucleus" in an expensive neighbourhood-say $£ 100$ or $£ 200$ a year, in a place where you and your family cannot possibly live on less than $£ 400$ or $£ 500$ a year.

Do you not think, Sir, that if the law of medical partnership. as applicable to dissolution thereof, were such as your article advocates, a premium would be placed upon fraud? That if partnership is to be dissolved on the ground of "incompatibility of temper," or any other flimsy plea of ready manu. facture, and the premium to be entirely retained, the "taking. in" a junior partner will become a most eligible and easy way of "raising the wind"?

"Selling partner," indeed! The innocent, unwary, and unprotected poor junior wonld most likely be "sold" with a vengeance.

Fortunately, however, for junior partners and for justice, the tendency of courts of equity is in the opposite direction to that which the senior partner or his counsel sighs for. Courts of equity feel that the junior partner requires quice as much protection, nay more, than the senior partner; and by a recent act "a power is given to courts of equity to award damages to the party injured by the breach of any covenant, contract, or agreement, and such damages may be in addition to, or in sub. stitution for, an order for specific performance." So beware, oh! ye "selling partners," how you treat partnerships evidently intended to last for many years as "partnerships at will." Beware how you trump up charges which you cannot substantiate, and manufacture pleas which will not hold water, in order to get rid of the bargain you repent. Depend upon it, instead of keeping the money you are so very fond of, yo' run a great risk of being made to pay more than you have received.

The article compares partnership to matrimony; allow me to assist in completing the analogy.

If, on marriage, the young lady, with a little fortune of her own, ran the risk of being turned ont of doors in a year or two, minus character and fortune, $M r$ r.Punch would scarcely need raise his paternal voice in the ejaculation "Don't!" Her own sense would surely lead her to avoid seduction and rohbery. So, if a junior partner, after prying a sum of money for an in troduction and an income stipulated to last ten or fourteen years, is to be liable to be discarded, minus character and money, after "one or two years" I need scarcely raise my voice in expnstulation agaiust what wruld very like turn out to be seduction and robbery.

His own instinct will surely teach him that he must avoid such fearful risks, and try his fortunes in a state of "singleblessedness." I am, Sir, your obedient servant,

September, 186 ?

A Junior Partiner.

\section{CHLORINE, AND THE CHLORINE ACIDS IN SCARLATINA;}

THEIR ACTION AS ANTIDOTES TO THE MORBID POISON OR TIRUS.

To the Elitor of Tre LANCET.

SIR, - Having read in THE LANCET for June 28th a paper by Mr. Conway T. Edwards on the treatment of scarlet fever by chlorine, and finding that gentleman has solicited the experi. ence of ather merical practitioners, I beg. in reply, to state that my attention has been given to the subject for some years past, and in Narch last I had the honour of reading a paper before the Southampton Nedical Society, embracing the pathological action of chlorine and the chlorine acids in scarlatina. In that paper I nointed out the remarlitble difference existing between the action of the chlorine acids and nitric and nitrous acids in that disease. - the former anpearing to exercise a direct action upon the morbid poison, while the lutter possessed no therapentical effects. The conclusion which I drew from the cases under observation was, that the chlorine acids are to the morbid poison of scarlatina what the nitric and nitrous acids* are to typhoid fever. In my hands, these oxygen acids have proved the most valuable therapentic agents in typhoid fever; but when they were given to patients labouring under scarlatina, or suppressed scarlatina taking typhoid symptoms, no beneficial effects resulted. On substituting, however, the chlorine acids for the oxygen acils, it favourable change took place, and the patients rapidly recovered.

\ow, although I have treated caser of scarlatina on the same physiolorical and chemical principles by nitric acid, I have never reversed my treatment. in order to try the effect of the chlorine acids in typhoii fever; but I have found the chlorine acids in scarlatina, and nitric acid in true typhoid, take precedence of ammonia as therapentic agents.

It may be necessary to state, that the olserrations which I have maile were in the absence of cerebral symptoms, owing to the mineral acids being contra indicated when such complications were present. Great care was also taken not to combine the acids with other remerial agents which tend to neutralize or mask their action; but a few drops of ipecacuanhat wine and syrup of poppies may be added to nitric acid, or to the hydrochloric, should bronchial or pulmonary complications require, without altering their action in a chemieal point of view; and when tonic treatment is necessary, the acids may be combined with decoction of bark or quinine.

When nitric acid bas been given to excess, the tongue becomes very red, and this is an indication for suspending its use, reducing the dose, or arministering an alkali, such as carbonate of soda, to which should be added a little pure ammonia or sal volatile, to absorb the carbonic acid which may be dis. engaged.

The prepzrations of chlorine which I have given in scarlatina are those in ordinary use: the nitro-bydrochloric acid; the hydrochloric; and the preparation recommended by Dr. Watson, of chlorate of potash and hydrochloric acid, which mixture contains, I believe, euchlorine.

I have never ventured to give the solution of chlorinated lime or soda internally, though I have frequently prescribed one or the other in the form of gargle. Children who are unable to use a gargle should have their fauces syringed with dilute nitro-hydrochloric acid or the euchlorine mixture; but in mild cases the internal use of these remedies is sufficient, without having recourse to syringing.

The hypothesis which I have advanced relating to the property of chlorine as an antidote to the virus of scarlatina re. quires further observations and investigation; but it is nevertheless worthy of note that nitric acid should possess the most powerful decomposing property of morbid matter, and prove so efficacious in typhoid, while the virus or morbid poison of scarlatina does not appear to be acted upon by it, or even removed from the system by its physiological action.

I have frequently watched patients whilst labouring under typhoid fever, and observed the rapidity with which nitric acid has cleared away the dusky hue and brightened the countenance, by decomposiug the morbid poison of the blood. If that dusky hue depended upon the feeble action of the heart, it should be removed by the exhibition of ammonia, which acts as a stimulant. On the contrary, however, $I$ have seen the dusky hue of the face increased by it, owing probably to the ammonia having an affinity for the morbid matter contained in the bloor.

I nnce treated a case of puerperal fever by carbonate of am. monia, and the yellonish dusky hue of the face was evidently increased by it; the patient, however, rallied slowly under its influence, by acting as a stimulant, until nature could throw off the morbid poison. Now, although ammonia is a safe stimulant, it required in this case to be given with caution, and it was sumetimes necessary to suspend it, and give the carbonte of sodic drink as recommenried by Dr. Rigby.

It is a question whether pnerperal fever of a typhoid type might not be advantagreously tre:ted with nitric or nitrous acid; but the mineral acids are liable to disagree when given in the puerperal state, by causing the milk to dry up.

Mr. Edwards in his paper mentions milk diet in fever; 1 have not recommended it in scarlatina or typhoid; but in cases of small-pox, as a drink, it has proved very beneficial.

Southampton, Aug. 1862. Hexpy OsBorn, M. R.C.P. Lond.

* Nitric acid containing vitrous, decomposes urea, and appears to possess this property when $i^{r}$ exists in execss in the liow. $t$ The activity of ipecaciatha ap:ears to be increased by mixirg it with
nitric acid, and the mixture lretucuty acts as an aperient. 